\title{
Vegetation mapping in an area of Ombrophilous Dense Forest at Parque Estadual da Serra do Mar, São Paulo State, Brazil, and floristic composition of the tree component of some physiognomies ${ }^{1}$
}

\author{
Maria Cláudia Melo Pacheco de Medeiros ${ }^{2,6}$, Isabel Fernandes de Aguiar Mattos³, Marina Mitsue Kanashiro², \\ Jorge Yoshio Tamashiro ${ }^{4}$ and Marcos Pereira Marinho Aidar ${ }^{5}$
}

Received: 18.01.2012; accepted: 17.05.2012

\begin{abstract}
Vegetation mapping in an area of Ombrophilous Dense Forest at Parque Estadual da Serra do Mar, São Paulo State, Brazil, and floristic composition of the tree component of some physiognomies). This study aimed to map phytophysiognomies of an area of Ombrophilous Dense Forest at Parque Estadual da Serra do Mar and characterize their floristic composition. Photointerpretation of aerial photographs in scale of 1:35,000 was realized in association with field work. Thirteen physiognomies were mapped and they were classified as Montane Ombrophilous Dense Forest, Alluvial Ombrophilous Dense Forest or Secondary System. Three physiognomies identified at Casa de Pedra streamlet's basin were studied with more details. Riparian forest (RF), valley forest (VF), and hill forest (HF) presented some floristic distinction, as confirmed by Detrended Correspondence Analysis (DCA) and Indicator Species Analysis (ISA) conducted here. Anthropic or natural disturbances and heterogeneity of environmental conditions may be the causes of physiognomic variation in the vegetation of the region. The results presented here may be useful to decisions related to management and conservation of Núcleo Santa Virgínia forests, in general.
\end{abstract}

Key words: Atlantic Forest, floristic survey, photointerpretation, phytophysiognomies

RESUMO - (Mapeamento da vegetação em área de Floresta Ombrófila Densa no Parque Estadual da Serra do Mar, SP, Brasil, e composição florística do componente arbóreo de algumas fisionomias). Este trabalho teve como objetivos mapear fitofisionomias de uma área de Floresta Ombrófila Densa no Parque Estadual da Serra do Mar e caracterizar sua composição florística. Realizou-se interpretação de fotografias aéreas, em escala de 1:35.000, associada a estudos de campo. Foram mapeadas 13 fitofisionomias, classificadas como Floresta Ombrófila Densa Montana, Floresta Ombrófila Densa Aluvial ou Sistema Secundário. Três fisionomias identificadas na microbacia do Córrego Casa de Pedra foram estudadas com mais detalhes. Floresta ripária (RF), Floresta de fundo de vale (VF) e Floresta de encosta (HF) apresentaram distinções florísticas, como confirmado pela Análise de Correspondência Distendida (DCA) e pela Análise de Espécies Indicadoras (ISA), aqui realizadas. Distúrbios antrópicos ou naturais e heterogeneidade ambiental podem ser as causas das variações fisionômicas na vegetação da região. Os resultados apresentados, de modo geral, podem ser úteis na tomada de decisões relacionadas ao manejo e à conservação das florestas do Núcleo Santa Virgínia.

Palavras-chave: fitofisionomias, Floresta Atlântica, fotointerpretação, levantamento florístico

\section{Introduction}

The Atlantic Forest covered, originally, more than $1,300,000 \mathrm{~km}^{2}$ of Brazilian territory, which represents about $15 \%$ of the total. Distributed along the coastal region, its boundaries covered areas of 17 States and portions of Argentina and Paraguay (Fundação S.O.S. Mata Atlântica \& INPE 2008). This area has great biological diversity and high rates of endemism (Mori et al. 1981) and is reduced to about $7.5 \%$ of

1. This work is part of the first Author's Master's Degree Dissertation by Program of Post graduation in Biodiversidade Vegetal e Meio Ambiente, Instituto de Botânica, São Paulo, SP, Brazil

2. Universidade de São Paulo, Instituto de Biociências, Departamento de Botânica, Caixa Postal 11461, 05422-970 São Paulo, SP, Brazil

3. Instituto Florestal, Divisão de Dasonomia, Rua do Horto, 931, 02377-000 São Paulo, SP, Brazil

4. Universidade Estadual de Campinas, Departamento de Biologia Vegetal, Caixa Postal 6109, 13083-970 Campinas, SP, Brazil

5. Instituto de Botânica, Núcleo de Pesquisa em Fisiologia e Bioquímica, Caixa Postal 68041, 04045-972 São Paulo, SP, Brazil

6. Corresponding author: mariaclaudiamedeiros@hotmail.com 
its original covering, which puts it among the most important global hotspots of biodiversity conservation (Myers et al. 2000).

The devastation of Atlantic Forest dates back to the history of colonization of Brazilian territory, and economic activities such as agriculture and industry and the urban expansion are among its main causes (Morellato \& Haddad 2000). The largest remaining forests are located in areas where destructive economic activities were not developed due to the rugged topography, such as Serra do Mar (Câmara 1990, Leitão-Filho 1994), although these areas are still under constant threat because of the proximity to large urban centers or areas of economic interest (Dean 1996, Morellato \& Haddad 2000).

The conservation of these remaining areas is also attributed to the presence of important conservation units (Franco et al. 2007). Among those located in São Paulo State it may be cited as examples the Parque Estadual da Ilha do Cardoso, Estação Ecológica Juréia-Itatins and Parque Estadual da Serra do Mar.

The Parque Estadual da Serra do Mar (PESM) was created in 1977 (Decreto No 10,251 of 30/08/1977) and covers an area of about 315,000 ha, located in the eastern portion of São Paulo State. Most of this area is on the escarpments of Serra do Mar, but some portions are located on Atlantic Plateau and Coastal Plain (Instituto Florestal 2006). Because it is a conservation unit with large covering area, PESM is managed through eight administrative units, three of them located at the Atlantic Plateau. Among them there is Núcleo Santa Virginia.

The vegetation of Núcleo Santa Virginia is predominantly comprised by Ombrophilous Dense Forest and, according to Tabarelli \& Mantovani (1999), part of that forest suffered clear cut and burn in the 1960s, and it is currently in the form of a mosaic, formed by areas of mature forest, grassland, plantations of Eucalyptus spp. and secondary forests at different ages of regeneration.

A very useful tool in studies of characterization of areas with fragmented or heterogeneous vegetation is the vegetation mapping. Küchler (1988) stated that vegetation maps are an integrated expression of local ecological conditions, characterizing it as an accurate way to portray plant communities and their different stages in some area. Thus, techniques of remote sensing and geographical information systems (GIS) have been successfully implemented because of its repetitiveness and capacity of interaction and analysis of different levels of information (Defries \& Townsend 1999).
The identification and mapping of spatial patterns of plant communities have received new boost in recent years, facing issues like global climate change and loss of biodiversity in various formations (Sánchez-Azofeifa et al. 1999, Foody 2002). However, studies involving mapping of vegetation in protected areas in larger scales are still necessary, especially those with complementary data about the floristic composition of the study area. They can be very useful in detailing the characterization of important remnants of highly endangered formations such as the Atlantic Forest. In São Paulo State, examples of studies involving mapping are those of Peccinini \& Pivello (2002), in Parque Estadual das Fontes do Ipiranga and Cardoso-Leite et al. (2005), in Reserva Biológica da Serra do Japi. Other works involved mapping of Atlantic Forest in São Paulo in areas outside of conservation units, such as Fidalgo (1995), in Baixada Santista and, more recently, Franco et al. (2007) in Embu. The latter work presented also a floristic list that resulted from the field assessment conducted in some fragments mapped.

Thus, this study aimed to realize the mapping of vegetation covering in an area of Ombrophilous Dense Forest at Parque Estadual da Serra do Mar, São Paulo State, Brazil, and also to characterize the floristic composition of the tree component of some physiognomies identified, and thus answering the following question: Are physiognomies studied characterized by distinct floristic groups?

\section{Material and methods}

Study area - Núcleo Santa Virgínia (coordinates between $23^{\circ} 17^{\prime}-23^{\circ} 24^{\prime} \mathrm{S}$ and $\left.45^{\circ} 03^{\prime}-45^{\circ} 11^{\prime} \mathrm{W}\right)$ at Parque Estadual da Serra do Mar has approximately 16,000 ha. It is inserted in a narrow strip of Atlantic Plateau between the coastal region and Paraíba Valley, covering the municipalities of São Luiz do Paraitinga and Natividade da Serra (Instituto Florestal 2006). The altitudes range from 860 to $1,500 \mathrm{~m}$ and the topography appears to be very steep, with straight slopes and valleys (Villani 1998). The predominant types of soil in the region are Red-Yellow Latosol, Cambisol and Litolic (Radambrasil 1983).

The regional climate can be classified as Cwa, according to Köeppen climatic classification (Setzer 1966), and the mean annual precipitation is 2,180 $\mathrm{mm}$. December, January and February are the most humid months of the year while June, July and August present the lowest precipitation volume. The 
average precipitation for each month exceeds $60 \mathrm{~mm}$ (São Paulo 1972).

The vegetation of the area is predominantly characterized by Montane Ombrophilous Dense Forest (Veloso et al. 1991).

This study is a result of a partnership between two Brazilian research projects (see Acknowledgments for more information) and the necessity for its implementation arose due to the installation of a micrometeorological tower in Núcleo Santa Virgínia, in the basin of Casa de Pedra streamlet, as predicted in the projects mentioned above. The tower provides the structure for equipments that measure atmospheric flow of energy, $\mathrm{H}_{2} \mathrm{O}$ and $\mathrm{CO}_{2}$ in order to estimate balance of energy, water and carbon in the surrounding areas. Thus, it became necessary to characterize the vegetation in the area of influence of the micrometeorological tower.

Phytophysiognomic mapping - Vegetation mapping was carried out to an area of about 1,950 ha which covers the Casa de Pedra streamlet's basin (115 ha, approximately) and surroundings, at Núcleo Santa Virgínia. The identification of different physiognomies in the study area was performed using bibliographic and cartographic materials (digital and printed), photointerpretation of vertical aerial photographs in natural color, obtained by BASE - Aerofotogrametria e Projetos S/A to SMA - Secretaria do Meio Ambiente do Estado de São Paulo, in 2001, on the scale of 1:35,000, and field verification.

Procedures used were based on the method employed by Lueder (1959) and Spurr (1960), which uses photographic image elements such as color, tone, texture, shape, size and combination of evidences to classify the vegetation, by photointerpretation of aerial photographs, establishing a correlation of photographic and structural elements of vegetation which are observed in the field, such as size of individuals, density, canopy features and other ecological conditions.

After the development of preliminary map, visits to Casa de Pedra streamlet's basin were made in order to check it at the field. Adjacent areas have not been visited and their physiognomies were identified only by aerial photographs analysis. During the field verification, features such as individuals' size, tree density, occurrence of gaps and presence of bamboo in different physiognomies were observed. After the field studies, there were made small corrections in preliminary map and then concluded the preparation of final map. Its digitization was made by scanning in georeferenced base to launch the polygons obtained by photointerpretation and than it was transferred to ArcView 3.2 (ESRI 1999) software to perform the final art.

Estimates of the area occupied by each physiognomy mapped in total area and in Casa de Pedra's basin were calculated in order to complement the characterization of this region. The estimates were also obtained using the program ArcView 3.2 (ESRI 1999).

Floristic composition - From the physiognomies mapped in Casa de Pedra's basin, three (physiognomies 01, 02 and 08 , presented in the next section) were selected for implementation of detailed floristic survey, based on phytosociological sampling of the tree component conducted in those areas (Medeiros $\&$ Aidar 2011). There were used contiguous plots of $10 \times 10 \mathrm{~m}$ aggregated in $20 \times 50 \mathrm{~m}\left(1,000 \mathrm{~m}^{2}\right)$ blocks. Two blocks ( 0.2 ha) were installed in each physiognomy, totaling 0.6 ha of sample area. All trees with stem perimeter at $1.30 \mathrm{~m}$ above the ground (or perimeter at breast height, $\mathrm{PBH}$ ) $\geq 15 \mathrm{~cm}$ were sampled. The physiognomies 01,02 and 08 are named throughout this work as hill forest (HF), valley forest (VF) and riparian forest (RF), respectively. Sampling areas were selected due to their representativity and accessibility.

Botanical material was collected at vegetative and/or reproductive stage. In the latter case, it was incorporated to Herbarium SP (Instituto de Botânica). Identifications were made by consulting appropriate literature, comparisons with specimens deposited in SP and UEC (Unicamp) and by sending material to specialists. The floristic list was drawn up in accordance with the classification proposed in APG III (2009). Confirmation and update of species names and authors were made by consulting the Lista de Espécies da Flora do Brasil 2012 database at http://floradobrasil. jbrj.gov.br/2012 (access in .10.05.2012).

In order to detect floristic patterns for the physiognomies, two techniques were applied to a matrix of species abundance data. Detrended Correspondence Analysis (DCA) (Hill \& Gauch 1980) was performed using the software PAST 2.12 (Hammer et al. 2001) and Indicator Species Analysis (ISA) (Dufrêne \& Legendre 1997) was carried out using the software PCORD 4.0 (McCune \& Mefford 1999). The statistical significance of species' indicator value was assessed via Monte Carlo randomizations. 


\section{Results and Discussion}

Phytophysiognomic mapping - Thirteen physiognomies were identified by photointerpretation (figure 1). From these, eight were grouped in the class Montane Ombrophilous Dense Forest, three in the class Alluvial Ombrophilous Dense Forest, which are characterized as formations associated with watercourses or located on flooded areas (Veloso et al. 1991), and two were grouped in the class Secondary System. The areas occupied by each class and their physiognomies are in table 1, where the predominance of the area covered by Montane Ombrophilous Dense Forest can be seen, in comparison with the other classes.

Alluvial areas showed variable tree size, since large (physiognomy 08), characterizing the riparian forests, going through medium (physiognomy 09), on restricted plains, up to small (physiognomy 10), on plains periodically flooded. In areas occupied by Montane Ombrophilous Dense Forest, similar situation was found, the size of trees varied from large (physiognomies 01,01 A and 02), medium (03, 04 and 07) to small (05 and 06). In Secondary System areas, both physiognomies (11 and 12) showed herbaceous size and were included.

For physiognomies with medium or large tree size from classes Montane Ombrophilous Dense Forest and Alluvial Ombrophilous Dense Forest, analysis of the characteristics of canopy uniformity led to comments related to the state of conservation of some of these physiognomies. For example, in physiognomies 02 , 04 and 07 , the occurrence of heterogeneous canopy or of canopy heights and spacing with high variation leaded to the observation that these areas have some degree of disturbance in its structure. This can be natural, as trees falls, for example, or anthropogenic, as wood removal. In physiognomy 07 , it was possible to identify by aerial photographs and also in subsequent field work, the presence of bamboos causing changes in the canopy of these areas. On the other hand, physiognomy 03 showed very uniform and homogeneous canopy, which led to the observation that it presents a good state of conservation.

In Casa de Pedra streamlet's basin, five physiognomies characterize the vegetation (figure 2): four from Montane Ombrophilous Dense Forest class and one from Alluvial Ombrophilous Dense Forest class. Within the former class of physiognomies, there were drawn some polygons that received the designation $01 \mathrm{~A}$ in the key. This is because these areas, when analyzed in aerial photos, showed similar features to physiognomy 01 , such as size and density of individuals, but it differs by the marked presence of Vochysia magnifica Warm. individuals, which was verified during the field work. Table 2 presents the estimated values of area occupied by each of them.

Structural differences in the vegetation of a given area can result from different causes, like disturbance regimes (cutting, burning and selective wood extraction, for example) and environmental heterogeneity (Alves \& Metzger 2006). The area of Núcleo Santa Virgínia presents effective human occupation for more than one hundred years since the establishment of a private property there (Tabarelli 1997). According to this author, some forest areas were replaced by small plantations, and as mentioned in the introduction, approximately $40 \%$ of original covering suffered burn and cut, about 50 years ago. In addition to this disturbance, different environmental characteristics at the local scale can determine the physiognomic and structural differences identified in the area mapped in this study.

According to Oliveira-Filho et al. (2001), on local scale, topographic variables, such as elevation and degree of land slope, for example, have been considered important causes of structural variation in tropical forests. This is directly related to changes in soil properties, that can lead to intricate patterns of resources availability such as water and nutrients, which influence the structure and composition of vegetation (Resende et al. 2002). Thus, the irregular topography that characterizes Núcleo Santa Virgínia region can determine differences in plant covering, because of the intrinsic relationship between topography and soil characteristics.

Besides the soil properties, topography determines the patterns of occurrence of watercourses in an area and the exposure sides of vegetation. Consequently, some microclimatic characteristics such as temperature and humidity can vary considerably in some regions, causing differences in structure and physiognomy of the vegetation, as observed by Cardoso-Leite (2000), in Reserva Biológica Municipal da Serra do Japi, São Paulo State.

Regarding structural changes in the canopy of some physiognomies, it was remarkable the presence of bamboos causing internal differences in the vegetation of Núcleo Santa Virgínia region. Physiognomy 07, visibly occupied by bamboos communities, was represented by a large number of polygons, which were responsible for $9.2 \%$ of the 


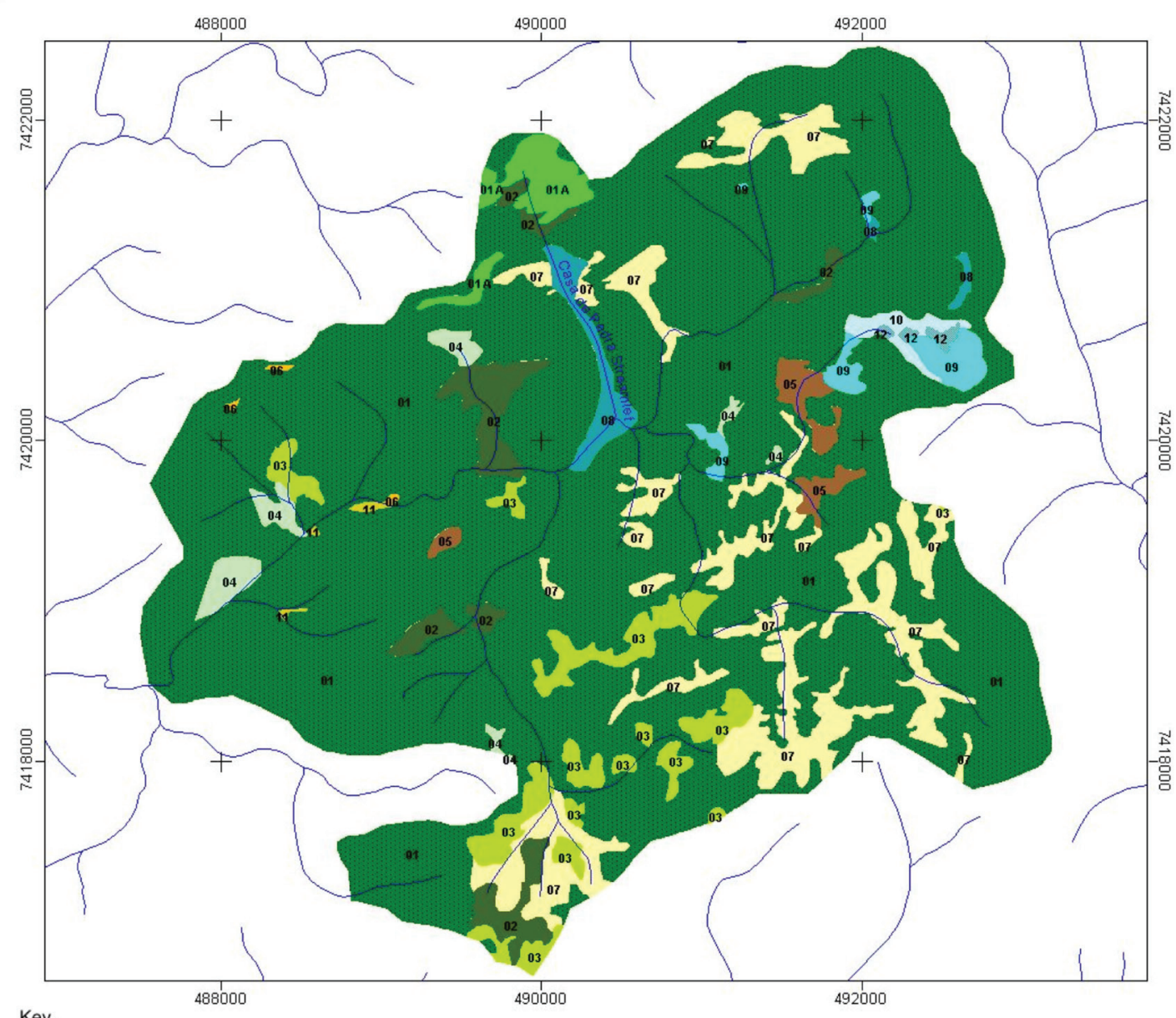

Key

Montane Ombrophilous Dense Forest

01 - vegetation with large tree size and uniform canopy

$01 \mathrm{~A}$ - vegetation with large tree size and uniform canopy (presence of Vochysia magnifica Warm.)

02 - vegetation with large tree size and heterogeneous canopy; shows some degree of disturbance

03 - vegetation with medium/large tree size and uniform canopy; shows good state of conservation

04 - vegetation with medium/small tree size and heterogeneous canopy; shows high degree of disturbance; absence of gaps

05 - vegetation with small/medium tree size and uniform canopy; small crowns; absence of gaps

06 - vegetation with small tree size and graminoids

07 - vegetation with medium/large tree size and heterogeneous canopy; shows high degree of disturbance due to the presence of bamboos, which occur in small or big clumps

Alluvial Ombrophilous Dense Forest

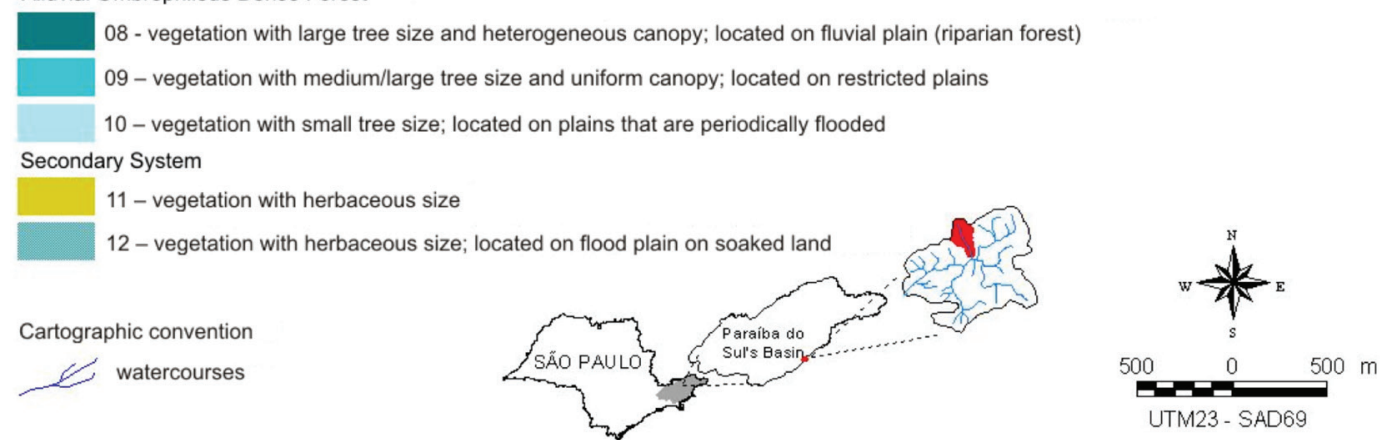

Figure 1. Phytophysiognomic map of an Ombrophilous Dense Forest area at Núcleo Santa Virgínia, Parque Estadual da Serra do Mar, São Paulo State, Brazil. 


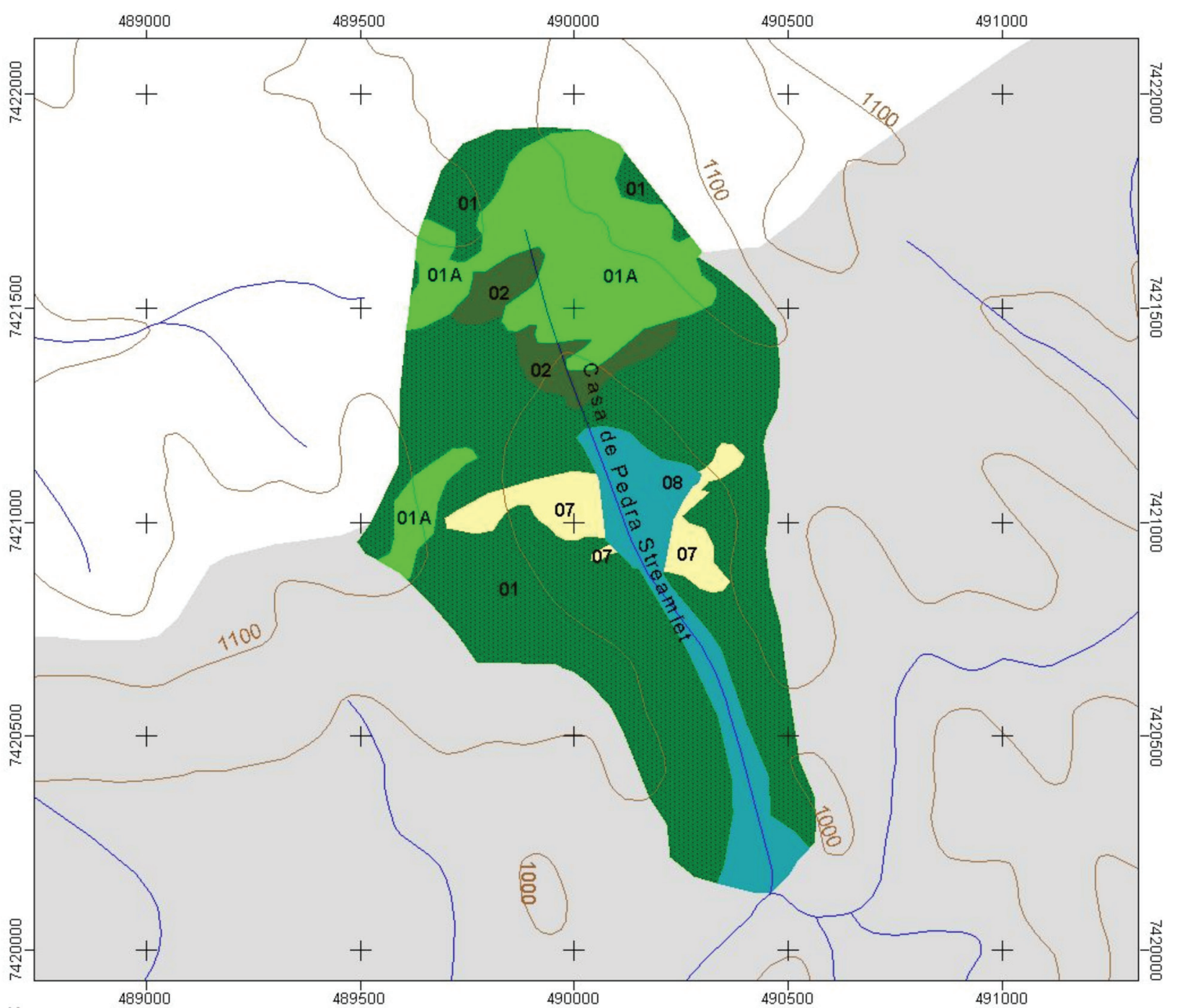

Key

Montane Ombrophilous Dense Forest

01 - vegetation with large tree size and uniform canopy

$01 \mathrm{~A}$ - vegetation with large tree size and uniform canopy (presence of Vochysia magnifica Warm.)

02 - vegetation with large tree size and heterogeneous canopy; shows some degree of disturbance

07 - vegetation with medium/large tree size and heterogeneous canopy; shows high degree of disturbance due to the presence of bamboos, which occur in small or big clumps

\section{Alluvial Ombrophilous Dense Forest}

08 - vegetation with large tree size and heterogeneous canopy; located on fluvial plain (riparian forest)

Cartographic convention

25 watercourses

goo contour
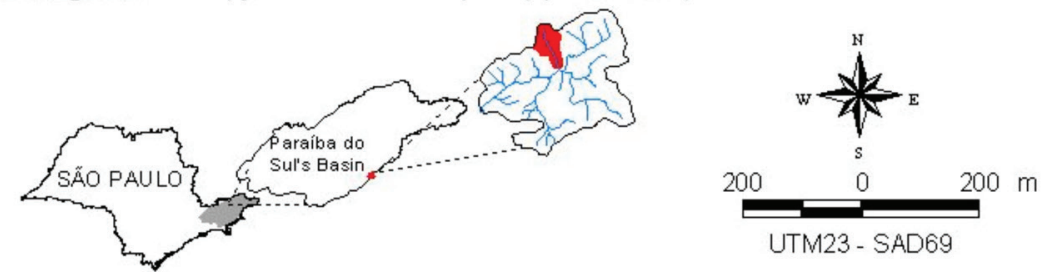

Figure 2. Ampliation of physiognomic map at Casa de Pedra streamlet's basin area, Núcleo Santa Virgínia, Parque Estadual da Serra do Mar, São Paulo State, Brazil. 
Table 1. Area occupied by physiognomies in total area mapped at Núcleo Santa Virgínia, Parque Estadual da Serra do Mar, São Paulo State, Brazil.

\begin{tabular}{lc}
\hline Class / Physiognomies & Area (ha) \\
\hline Montane Ombrophilous Dense Forest & - \\
Physiognomy 01 & $1,515.46$ \\
Physiognomy 01A & 24.60 \\
Physiognomy 02 & 56.00 \\
Physiognomy 03 & 72.25 \\
Physiognomy 04 & 22.49 \\
Physiognomy 05 & 19.75 \\
Physiognomy 06 & 1.21 \\
Physiognomy 07 & 180.87 \\
Total & $1,892.63$ \\
Alluvial Ombrophilous Dense Forest & - \\
Physiognomy 08 & 22.59 \\
Physiognomy 09 & 21.33 \\
Physiognomy 10 & 9.41 \\
Total & 53.33 \\
Secondary System & - \\
Physiognomy 11 & 2.01 \\
Physiognomy 12 & 3.37 \\
Total & 5.38 \\
\hline
\end{tabular}

total mapped area. Tabarelli \& Mantovani (1999) have noted the frequent presence of bamboo in illuminated habitats of the forests in the region, such as the tops of hills and the rivers edge. The same authors in subsequent work (Tabarelli \& Mantovani 2000) discussed the presence of bamboo colonizing gaps in those forests, and being part of the succession process there.

Floristic data - For the total of 1,046 individuals sampled in Casa de Pedra streamlet's basin, there were listed 119 species belonging to 65 genera and 35 families. Twelve species had their identification at the level of genus and three at families (table 3).

Regarding species richness, Myrtaceae (31 species), Lauraceae (10), Rubiaceae (nine), Fabaceae (six), Sapindaceae and Asteraceae (five each) highlighted in the total sampling. They accounted together for $55 \%$ of total recorded species. Fifteen families (44\%) presented only one species. Among the genera, there were remarkable for their richness Myrcia (eight species), Eugenia (seven),
Marlierea (six), Inga (five), Mollinedia and Ocotea (four each), totaling $28 \%$ of the total sampled.

Analyzing separately the floristic composition of the physiognomies studied, we observed that the richest families in each of them are cited among that with high species richness in the total sampling. Myrtaceae is the family with greatest number of species in all study area, with 12 species in RF, 16 in VF and 21 in HF. Lauraceae contributed mainly to the richness of RF (four species) and HF (seven species) and Rubiaceae to VF (five species) and HF (six species), mainly. The other families contributed distinctly to the floristic composition of the areas, and some were exclusive to one of the three physiognomies studied: Phyllanthaceae is present only in RF, Aquifoliaceae, Malpighiaceae, Olacaceae, Schoepfiaceae, Siparunaceae and Solanaceae only in VF and Araliaceae, Clusiaceae, Magnoliaceae and Moraceae only in HF. Except for Araliaceae and Solanaceae, with two species, such families are each represented by only one species.

It is noteworthy that the richest families listed in this study, particularly Myrtaceae, Lauraceae, Rubiaceae and Fabaceae were also cited in other studies realized in areas of Atlantic Forest, for example, Silva \& Leitão-Filho (1982) and Sanchez et al. (1999), in Serra do Mar, Guilherme et al. (2004), in Serra de Paranapiacaba and Gomes et al. (2005), Catharino et al. (2006) and Ogata \& Gomes (2006) in Atlantic Plateau, confirming its importance in the general characterization of this domain in southeastern Brazil. Euphorbiaceae and Melastomataceae are also cited as important in this characterization (Ivanauskas et al. 2001, Zipparo et al. 2005) and although they are not among the families of greatest richness in this study, they were represented by two and four species, respectively. Mantovani (1993) noted also that Myrtaceae, Lauraceae and Fabaceae are families usually well represented in montane formations near the coast of São Paulo, like others sampled in this study, although with smaller species number, such as Cyatheaceae, Sapotaceae and Aquifoliaceae.

Similarly, the genera that presented high species richness in this study are among those with greatest number of tree species in the 102 areas of Atlantic Forest examined by Oliveira-Filho \& Fontes (2000). Eugenia must be emphasized, because it presented high species richness in studies conducted in other Ombrophilous Dense Forest areas located in São Paulo (Melo \& Mantovani 1994, Sanchez et al. 
Table 2. Area occupied by physiognomies in Casa de Pedra streamlet's basin area, Núcleo Santa Virgínia, Parque Estadual da Serra do Mar, São Paulo State, Brazil.

\begin{tabular}{lc}
\hline Class / Physiognomies & Area (ha) \\
\hline Montane Ombrophilous Dense Forest & - \\
Physiognomy 01 & 68.19 \\
Physiognomy 01A & 22.95 \\
Physiognomy 02 & 5.32 \\
Physiognomy 07 & 6.00 \\
Total & 102.46 \\
Alluvial Ombrophilous Dense Forest & - \\
Physiognomy 08 & 12.53 \\
Total & 12.53 \\
\hline
\end{tabular}

1999, Ivanauskas et al. 2001). Ocotea and Myrcia also should receive emphasis because they presented high species number in another area of Montane Ombrophilous Dense Forest in Reserva Florestal do Morro Grande (Cotia, SP), studied by Catharino et al. (2006).

Regarding the occurrence of species in physiognomies, it was observed that the greatest number was found in HF, 76 species, and the fewest in RF, 54. VF, in turn, presented 64 species. HF also presented the highest number of exclusive species ( 29 , corresponding to $24 \%$ of total) when compared with RF and VF with, respectively, $14(12 \%)$ and 20 (17\%) exclusive species. Of the 56 remaining species, 37 (31\% of total) are present in two of the three physiognomies and $19(16 \%)$ have representatives in the three areas of study.

Among the species that occurred in the three sampled areas, Alchornea triplinervia, Cabralea canjerana, Matayba guianensis and Myrciaria floribunda are considered widely distributed within the Atlantic domain. Campomanesia guaviroba, Alseis floribunda, Euterpe edulis, Myrcia pubipetala and Ocotea dispersa are considered typical of lowland Atlantic forests and Psychotria suterella of higher altitudes (Oliveira-Filho \& Fontes 2000). In the latter category there are also other species that occurred in one or two physiognomies in this study and, according to the same authors, are typical of montane formations: Casearia obliqua (occurred just in VF), Cryptocarya saligna (HF), Heisteria silvianii (VF), Mollinedia argyrogyna (VF and HF), Nectandra puberula (RF), Schefflera angustissima and S. calva (HF).

$\mathrm{RF}$ is the riparian forest that borders Casa de Pedra streamlet. Some exclusive species of this physiognomy seem being typical of environments of moist soil, such as Blepharocalyx salicifolius and Allophylus edulis (Lorenzi 2002a, b). Guarea macrophylla and Inga marginata are also species that characterize riparian forests (Sanchez et al. 1999) and occurred in this area, although they are not exclusive of it. VF presents, among its exclusive species, Casearia decandra, which is common in open areas that have suffered some disturbance (Lorenzi 2002b). In fact, this physiognomy is characterized by the presence of large gaps and of bamboos' clumps in some portions, what suggests that this area may have suffered some natural or anthropogenic disturbance. HF, in turn, presented among its exclusive species Nectandra membranacea, Inga sessilis, Talauma ovata, Guapira opposita and Syagrus romanzoffiana, which occur preferably in moist soil areas (Lorenzi 2002a, b). This is due, possibly, to the fact that some of the plots were located near the fluvial plain, where the soil must be moister.

Quantitative analyses - Quantitative analyses confirm that there is some floristic differentiation among the physiognomies. Analyzing the DCA diagram it is possible to detect some groups of plots for each physiognomy, especially for RF and VF (figure 3). Eigenvalues for axis 1 and 2 were 0.5671 and 0.3678 , respectively. Distribution of plots in the diagram shows that RF plots are located mostly in the left and lower sides of the diagram and VF plots in the lower and right sides. HF plots, in turn, are more scattered throughout the diagram, especially in its central portion.

ISA results presented as significantly $(p<0.05)$ indicative species of RF (in descending order of indicator value): Alsophila sternbergii, Vernonanthura puberula, Myrcia pubipetala, Eugenia sp.1, Cabralea canjerana, Inga marginata and Allophylus edulis. For VF, the species with significant indicator values were Psychotria suterella, Marlierea obscura, Psychotria nemorosa and Marlierea suaveolens. For HF, in turn, there were Alchornea triplinervia, Bathysa stipulata, Inga lanceifolia and Schefflera calva.

ISA method takes into account parameters such as relative abundance and frequency of the species to generate indicator values for them. Thus, it is expected that the results of ISA analysis illustrate some structural features of the community that is being studied when associate to it a floristic ranking of indicative species. In fact, part of the results obtained, 


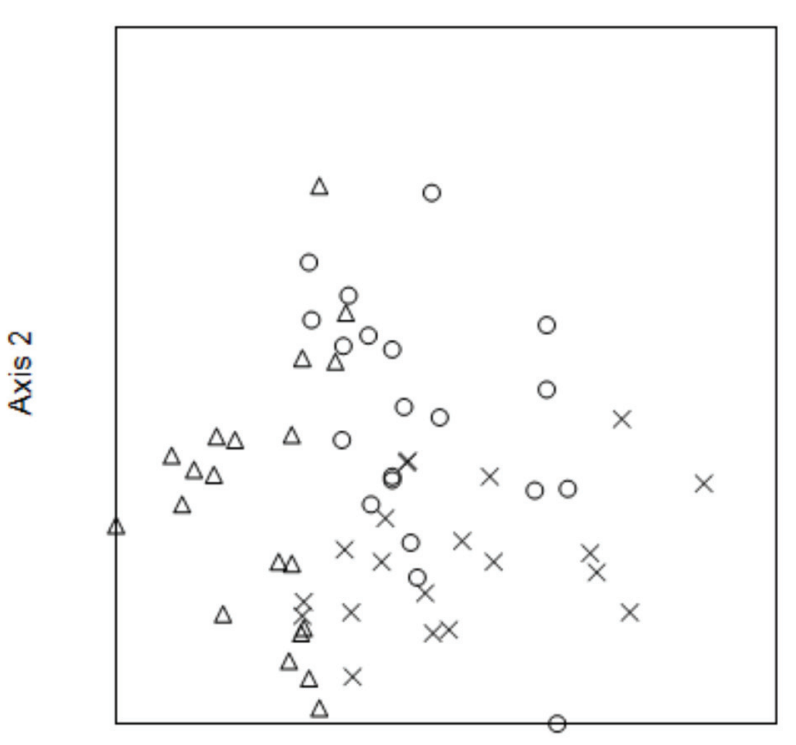

Axis 1

Figure 3. Two-dimensional plots ordination diagram derived from DCA. Triangles: Plots from riparian forest (RF); Crosses: Plots from valley forest (VF); Circles: Plots from hill forest (HF). especially for RF and HF, corroborate structural data of the studied physiognomies that are discussed in Medeiros \& Aidar (2011). In RF, for example, Alsophila sternbergii and Eugenia sp.1 show high density of trees and Vernonanthura puberula and Myrcia pubipetala show high values of frequency. In VF, Psychotria suterella show high density of trees and in HF, in turn, Bathysa stipulata highlights because of the density of trees and Inga lanceifolia for its frequency.

Thus, in general, the results presented in this work show that the evident structural variation among the phytophysiognomies, that led to their delimitation and was also discussed elsewhere (Medeiros \& Aidar 2011), can be associated to some floristic variation too. We expect this work may be useful to decisions related to management and conservation of Núcleo Santa Virgínia forests, in general, since they provide a general idea about how vegetation is distributed in the area mapped and its ecological conditions. Moreover, the floristic characterization of

Table 3. List of families and species sampled in an Ombrophilous Dense Forest area at Núcleo Santa Virgínia, Parque Estadual da Serra do Mar, São Paulo State, Brazil, and indication of presence in physiognomies studied. RF: Riparian forest; VF: Valley forest; HF: Hill forest.

\begin{tabular}{|c|c|c|c|}
\hline Family/Specie & $\mathrm{RF}$ & VF & $\mathrm{HF}$ \\
\hline ANNONACEAE & - & - & - \\
\hline Guatteria sp. & - & $\mathrm{X}$ & $\mathrm{X}$ \\
\hline Annona dolabripetala Raddi & $X$ & $\mathrm{X}$ & - \\
\hline AQUIFOLIACEAE & - & - & - \\
\hline Ilex paraguariensis A. St.-Hil. & - & $\mathrm{X}$ & - \\
\hline ARALIACEAE & - & - & - \\
\hline Schefflera angustissima (Marchal) Frodin & - & - & $\mathrm{X}$ \\
\hline Schefflera calva (Cham.) Frodin \& Fiaschi & - & - & $X$ \\
\hline ARECACEAE & - & - & - \\
\hline Euterpe edulis Mart. & $\mathrm{X}$ & $\mathrm{X}$ & $\mathrm{X}$ \\
\hline Syagrus romanzoffiana (Cham.) Glassman & - & - & $\mathrm{X}$ \\
\hline ASTERACEAE & - & - & - \\
\hline Piptocarpha macropoda (DC.) Baker & - & - & $\mathrm{X}$ \\
\hline Vernonanthura divaricata (Spreng.) H. Rob. & $\mathrm{X}$ & - & $X$ \\
\hline Vernonianthura discolor (Spreng.) H. Rob. & $\mathrm{X}$ & - & - \\
\hline Vernonanthura puberula (Less.) H. Rob. & $\mathrm{X}$ & $\mathrm{X}$ & $\mathrm{X}$ \\
\hline Asteraceae sp. & $\mathrm{X}$ & - & - \\
\hline BORAGINACEAE & - & - & - \\
\hline Cordia trichoclada DC. & $\mathrm{X}$ & $\mathrm{X}$ & - \\
\hline
\end{tabular}


Table 3 (continuation)

\begin{tabular}{|c|c|c|c|}
\hline Family/Specie & $\mathrm{RF}$ & $\mathrm{VF}$ & $\mathrm{HF}$ \\
\hline CARDIOPTERIDACEAE & - & - & - \\
\hline Citronella paniculata (Mart.) R.A. Howard & $\mathrm{X}$ & - & $\mathrm{X}$ \\
\hline CELASTRACEAE & - & - & - \\
\hline Maytenus sp.1 & - & $\mathrm{X}$ & - \\
\hline Maytenus sp.2 & - & - & $\mathrm{X}$ \\
\hline CHRYSOBALANACEAE & - & - & - \\
\hline Licania kunthiana Hook. f. & - & $\mathrm{X}$ & $\mathrm{X}$ \\
\hline CLUSIACEAE & - & - & - \\
\hline Garcinia gardneriana (Planch. \& Triana) Zappi & - & - & $\mathrm{X}$ \\
\hline CYATHEACEAE & - & - & - \\
\hline Alsophila sternbergii (Sternb.) D.S. Conant & $\mathrm{X}$ & $\mathrm{X}$ & $\mathrm{X}$ \\
\hline Cyathea delgadii Sternb. & $\mathrm{X}$ & & $\mathrm{X}$ \\
\hline Cyathea phalerata Mart. & $\mathrm{X}$ & $\mathrm{X}$ & $\mathrm{X}$ \\
\hline ELAEOCARPACEAE & - & - & - \\
\hline Sloanea hirsuta (Schott) Planch. ex Benth. & - & $\mathrm{X}$ & $\mathrm{X}$ \\
\hline EUPHORBIACEAE & - & - & - \\
\hline Alchornea triplinervia (Spreng.) Müll. Arg. & $\mathrm{X}$ & $\mathrm{X}$ & $\mathrm{X}$ \\
\hline Tetrorchidium rubrivenium Poepp. & $\mathrm{X}$ & - & $\mathrm{X}$ \\
\hline FABACEAE & - & - & - \\
\hline Inga cf. lanceifolia Benth. & $\mathrm{X}$ & - & - \\
\hline Inga cf. arenicola T.D. Penn. & - & $\mathrm{X}$ & - \\
\hline Inga lanceifolia Benth. & - & $\mathrm{X}$ & $\mathrm{X}$ \\
\hline Inga marginata Willd. & $\mathrm{X}$ & - & $\mathrm{X}$ \\
\hline Inga sessilis (Vell.) Mart. & - & - & $\mathrm{X}$ \\
\hline Pterocarpus rohrii Vahl & $\mathrm{X}$ & - & $\mathrm{X}$ \\
\hline LAURACEAE & - & - & - \\
\hline Cryptocarya mandioccana Meisn. & - & $\mathrm{X}$ & $\mathrm{X}$ \\
\hline Cryptocarya moschata Nees \& Mart. & $\mathrm{X}$ & - & - \\
\hline Cryptocarya saligna $\mathrm{Mez}$ & - & - & $\mathrm{X}$ \\
\hline Nectandra membranacea (Sw.) Griseb. & - & - & $\mathrm{X}$ \\
\hline Nectandra puberula (Schott) Nees & $\mathrm{X}$ & - & - \\
\hline Ocotea catharinensis $\mathrm{Mez}$ & - & - & $\mathrm{X}$ \\
\hline Ocotea daphnifolia (Meisn.) Mez & - & $\mathrm{X}$ & - \\
\hline Ocotea dispersa (Nees \& Mart.) Mez & $\mathrm{X}$ & $\mathrm{X}$ & $\mathrm{X}$ \\
\hline Ocotea glaziovii Mez & $\mathrm{X}$ & - & $\mathrm{X}$ \\
\hline Rhodostemonodaphne macrocalyx (Meisn.) Rohwer ex Madriñán & - & - & $\mathrm{X}$ \\
\hline MAGNOLIACEAE & - & - & - \\
\hline Magnolia ovata (A.St.-Hil.) Spreng. & - & - & $\mathrm{X}$ \\
\hline
\end{tabular}


Table 3 (continuation)

\begin{tabular}{|c|c|c|c|}
\hline Family/Specie & RF & VF & $\mathrm{HF}$ \\
\hline MALPIGHIACEAE & - & - & - \\
\hline Byrsonima sp. & - & $\mathrm{X}$ & - \\
\hline MELASTOMATACEAE & - & - & - \\
\hline Leandra barbinervis (Cham. ex Triana) Cogn. & $\mathrm{X}$ & $\mathrm{X}$ & $\mathrm{X}$ \\
\hline Miconia cabucu Hoehne & - & $\mathrm{X}$ & - \\
\hline Miconia sp. & - & - & $\mathrm{X}$ \\
\hline Tibouchina pulchra Cogn. & $\mathrm{X}$ & - & $\mathrm{X}$ \\
\hline MELIACEAE & - & - & - \\
\hline Cabralea canjerana (Vell.) Mart. & $\mathrm{X}$ & $\mathrm{X}$ & $\mathrm{X}$ \\
\hline Cedrela fissilis Vell. & $\mathrm{X}$ & $\mathrm{X}$ & - \\
\hline Guarea macrophylla Vahl & $\mathrm{X}$ & - & $\mathrm{X}$ \\
\hline Trichilia pallens C.DC. & $\mathrm{X}$ & $\mathrm{X}$ & - \\
\hline MONIMIACEAE & - & - & - \\
\hline Mollinedia argyrogyna Perkins & - & $\mathrm{X}$ & $\mathrm{X}$ \\
\hline Mollinedia blumenaviana Perkins & - & $\mathrm{X}$ & $\mathrm{X}$ \\
\hline Mollinedia engleriana Perkins & $\mathrm{X}$ & $\mathrm{X}$ & $\mathrm{X}$ \\
\hline Mollinedia schottiana (Spreng.) Perkins & - & $\mathrm{X}$ & - \\
\hline MORACEAE & - & - & - \\
\hline Sorocea bonplandii (Baill.) W.C. Burger, Lanj. \& Wess. Boer & - & - & $\mathrm{X}$ \\
\hline MYRSINACEAE & - & - & - \\
\hline Myrsine gardneriana A. DC. & $\mathrm{X}$ & - & $\mathrm{X}$ \\
\hline Myrsine hermogenesii (Jung-Mend. \& Bernacci) M.F.-Freitas \& Kin.-Gouv. & - & - & $\mathrm{X}$ \\
\hline MYRTACEAE & - & - & - \\
\hline Blepharocalyx salicifolius (Kunth) O. Berg & $\mathrm{X}$ & - & - \\
\hline Calyptranthes lucida Mart. ex DC. & - & $\mathrm{X}$ & $\mathrm{X}$ \\
\hline Calyptranthes strigipes $\mathrm{O}$. Berg & - & - & $\mathrm{X}$ \\
\hline Campomanesia guaviroba (DC.) Kiaersk. & $\mathrm{X}$ & $\mathrm{X}$ & $\mathrm{X}$ \\
\hline Eugenia cf. cerasiflora Miq. & - & & $\mathrm{X}$ \\
\hline Eugenia oblongata O. Berg. & $\mathrm{X}$ & - & - \\
\hline Eugenia platysema $\mathrm{O}$. Berg & $\mathrm{X}$ & - & - \\
\hline Eugenia prasina $\mathrm{O}$. Berg & - & - & $\mathrm{X}$ \\
\hline Eugenia ternatifolia Cambess. & $\mathrm{X}$ & $\mathrm{X}$ & $\mathrm{X}$ \\
\hline Eugenia sp.1 & $\mathrm{X}$ & $\mathrm{X}$ & $\mathrm{X}$ \\
\hline Eugenia sp.2 & - & - & $\mathrm{X}$ \\
\hline Marlierea cf. excoriata Mart. & - & - & $\mathrm{X}$ \\
\hline Marlierea cf. racemosa (Vell.) Kiaersk. & - & $\mathrm{X}$ & - \\
\hline Marlierea obscura O. Berg & - & $\mathrm{X}$ & $\mathrm{X}$ \\
\hline Marlierea silvatica (O. Berg) Kiaersk. & $\mathrm{X}$ & $\mathrm{X}$ & - \\
\hline
\end{tabular}


Table 3 (continuation)

\begin{tabular}{|c|c|c|c|}
\hline Family/Specie & $\mathrm{RF}$ & $\mathrm{VF}$ & $\mathrm{HF}$ \\
\hline Marlierea suaveolens Cambess. & - & $\mathrm{X}$ & - \\
\hline Marlierea sp. & - & $\mathrm{X}$ & - \\
\hline Myrceugenia glaucescens (Cambess.) D. Legrand \& Kausel & - & - & $\mathrm{X}$ \\
\hline Myrceugenia myrcioides (Cambess.) O. Berg & $\mathrm{X}$ & $\mathrm{X}$ & - \\
\hline Myrceugenia seriatoramosa (Kiaersk.) D. Legrand \& Kausel & - & - & $\mathrm{X}$ \\
\hline Myrcia amazonica DC. & - & - & $\mathrm{X}$ \\
\hline Myrcia cf. guianensis (Aubl.) DC. & - & - & $\mathrm{X}$ \\
\hline Myrcia pubipetala Miq. & $\mathrm{X}$ & $\mathrm{X}$ & $\mathrm{X}$ \\
\hline Myrcia spectabilis DC. & - & - & $\mathrm{X}$ \\
\hline Myrcia splendens (Sw.) DC. & $\mathrm{X}$ & - & $\mathrm{X}$ \\
\hline Myrcia tenuivenosa Kiaersk. & $\mathrm{X}$ & - & - \\
\hline Myrcia tijucensis Kiaersk. & - & $\mathrm{X}$ & $\mathrm{X}$ \\
\hline Myrcia sp. & - & $\mathrm{X}$ & $\mathrm{X}$ \\
\hline Myrciaria floribunda (H. West ex Willd.) O. Berg & $\mathrm{X}$ & $\mathrm{X}$ & $\mathrm{X}$ \\
\hline Myrciaria sp. & - & $\mathrm{X}$ & - \\
\hline Myrtaceae sp. & - & $\mathrm{X}$ & $\mathrm{X}$ \\
\hline NYCTAGINACEAE & - & - & - \\
\hline Guapira areolata (Heimerl) Lundell & $\mathrm{X}$ & $\mathrm{X}$ & $\mathrm{X}$ \\
\hline Guapira opposita (Vell.) Reitz & - & - & $\mathrm{X}$ \\
\hline OLACACEAE & - & - & - \\
\hline Heisteria silvianii Schwacke & - & $\mathrm{X}$ & - \\
\hline PHYLLANTHACEAE & - & - & - \\
\hline Hieronyma alchorneoides Allemão & $\mathrm{X}$ & - & - \\
\hline RUBIACEAE & - & - & - \\
\hline Alseis floribunda Schott & $\mathrm{X}$ & $\mathrm{X}$ & $\mathrm{X}$ \\
\hline Bathysa australis (A. St.-Hil.) K. Schum. & $\mathrm{X}$ & - & - \\
\hline Bathysa stipulata (Vell.) C. Presl & $\mathrm{X}$ & $\mathrm{X}$ & $\mathrm{X}$ \\
\hline Posoqueria latifolia (Rudge) Roem. \& Schult. & - & - & $\mathrm{X}$ \\
\hline Psychotria nemorosa Gardner & - & $\mathrm{X}$ & - \\
\hline Psychotria suterella Müll. Arg. & $\mathrm{X}$ & $\mathrm{X}$ & $\mathrm{X}$ \\
\hline Psychotria vellosiana Benth. & - & $\mathrm{X}$ & - \\
\hline Rudgea sp. & - & - & $\mathrm{X}$ \\
\hline Rubiaceae sp. & - & - & $\mathrm{X}$ \\
\hline SALICACEAE & - & - & - \\
\hline Casearia decandra Jacq. & & $\mathrm{X}$ & - \\
\hline Casearia obliqua Spreng. & $\mathrm{X}$ & - & - \\
\hline Casearia sylvestris $\mathrm{Sw}$. & $\mathrm{X}$ & $\mathrm{X}$ & - \\
\hline SAPINDACEAE & - & - & - \\
\hline Allophylus edulis (A. St.-Hil., A. Juss. \& Cambess.) Hieron. ex Niederl. & $\mathrm{X}$ & - & - \\
\hline
\end{tabular}


Table 3 (continuation)

\begin{tabular}{lccc}
\hline Family/Specie & $\mathrm{RF}$ & $\mathrm{VF}$ & $\mathrm{HF}$ \\
\hline Cupania oblongifolia Mart. & $\mathrm{X}$ & - & - \\
Cupania vernalis Cambess. & - & $\mathrm{X}$ & $\mathrm{X}$ \\
Cupania sp. & $\mathrm{X}$ & - & $\mathrm{X}$ \\
Matayba guianensis Aubl. & $\mathrm{X}$ & $\mathrm{X}$ & $\mathrm{X}$ \\
SAPOTACEAE & - & - & - \\
Chrysophyllum viride Mart. \& Eichler & $\mathrm{X}$ & $\mathrm{X}$ & - \\
Micropholis crassipedicellata (Mart. \& Eichler ex Miq.) Pierre & $\mathrm{X}$ & $\mathrm{X}$ & - \\
Pouteria caimito (Ruiz \& Pav.) Radlk. & - & $\mathrm{X}$ & $\mathrm{X}$ \\
Pouteria psammophila (Mart.) Radlk. & - & $\mathrm{X}$ & - \\
SCHOEPFIACEAE & - & - & - \\
Schoepfia brasiliensis A.DC. & - & $\mathrm{X}$ & - \\
SIPARUNACEAE & - & - & - \\
Siparuna brasiliensis (Spreng.) A. DC. & - & $\mathrm{X}$ & - \\
SOLANACEAE & - & - & - \\
Cestrum schlechtendalii G. Don & - & $\mathrm{X}$ & - \\
Solanum cf. didymum Dunal & - & $\mathrm{X}$ & - \\
THYMELAEACEAE & - & - & - \\
Daphnopsis schwackeana Taub. & - & $\mathrm{X}$ & $\mathrm{X}$ \\
URTICACEAE & - & - & - \\
Coussapoa microcarpa (Schott) Rizzini & - & $\mathrm{X}$ & $\mathrm{X}$ \\
\hline
\end{tabular}

some of the identified physiognomies can also serve as a basis for such decisions, since they provide data about the heterogeneity of species groups in the study area.

\section{Acknowledgements}

The authors would like to acknowledge the Conselho Nacional de Desenvolvimento Científico e Tecnológico $(\mathrm{CNPq})$ for the scholarship awarded to first author; the Fundação de Amparo à Pesquisa do Estado de São Paulo (FAPESP) for the funding for the projects "Composição florística, estrutura e funcionamento da Floresta Ombrófila Densa dos Núcleos Picinguaba e Santa Virgínia do Parque Estadual da Serra do Mar" (Process number 03/12595-7), under coordination of Dr. Carlos Alfredo Joly (IB / UNICAMP) and "O balanço de carbono sobre uma floresta de Mata Atlântica com medidas micrometeorológicas e biométricas" (07/57465-4), under the coordination of Dr. Humberto Ribeiro da Rocha (IAG / USP); all colleagues who helped in field work; all taxonomists who helped with the identification of the material collected and to Amanda Catarucci for the help with the initial maps digitization.

\section{Literature cited}

Alves, L.F. \& Metzger, J.P. 2006. A regeneração florestal em áreas de floresta secundária na Reserva Florestal do Morro Grande, Cotia, SP. Biota Neotropica 6. Available at http://www.biotaneotropica.org.br/ $\mathrm{v} 6 \mathrm{n} 2 / \mathrm{pt} / \mathrm{abstract}$ ?article+bn00406022006. (access in 01.11.2008).

APG III. 2009. An update of the Angiosperm Phylogeny Group classification for the orders and families of flowering plants: APG III. Botanical Journal of the Linnean Society 161: 105-121.

Câmara, I.G. 1990. Mata Atlântica. Editora Index \& Fundação S.O.S. Mata Atlântica, Rio de Janeiro.

Cardoso-Leite, E. 2000. A vegetação de uma Reserva Biológica Municipal: contribuição ao manejo e à conservação da Serra do Japi, Jundiaí, SP. Tese de Doutorado, Universidade Estadual de Campinas, Campinas. 
Cardoso-Leite, E., Pagani, M.I., Monteiro, R. \& Hamburger, D.S. 2005. Ecologia da paisagem: mapeamento da vegetação da Reserva Biológica da Serra do Japi, Jundiaí, SP, Brasil. Acta Botanica Brasilica 19: 233-243.

Catharino, E.L., Bernacci, L.C., Franco, G.A.D.C., Durigan, G. \& Metzger, J.P. 2006. Aspectos da composição e diversidade do componente arbóreo das florestas da Reserva Florestal do Morro Grande, Cotia, SP. Biota Neotropica 6. Available at http://biotaneotropica. org.br/v6n2/pt/abstract?artic le+bn00306022006 (access in 01.11.2008).

Dean, W. 1996. A ferro e fogo. A história e a devastação da Mata Atlântica brasileira. Companhia das Letras, São Paulo.

Defries, R.S. \& Townsend, J.R.G. 1999. Global land cover characterization from satellite data: from research to operational implementation? Global Ecology and Biogeography 8: 367-379.

Dufrêne, M. \& Legendre, P. 1997. Species assemblages and indicator species: the need for a flexible asymmetrical approach. Ecological Monographs 67: 345-366.

ESRI. 1999. ArcView 3.2. Environmental Systems Research Institute, Redlands.

Fidalgo, E.C.C.F. 1995. Exatidão no processo de mapeamento temático da vegetação de uma área de Mata Atlântica no Estado de São Paulo, a partir de imagens TM-Landsat. Dissertação de Mestrado, Instituto Nacional de Pesquisas Espaciais, São José dos Campos.

Foody, G.M. 2002. Status of land cover classification accuracy assessment. Remote Sensing of Environment 80: 185-201.

Franco, G.A.D.C., Souza, F.M., Ivanauskas, N.M., Mattos, I.F.A., Baitello, J.B., Aguiar, O.T., Catarucci, A.F.M. \& Polisel, R.T. 2007. Importância dos remanescentes florestais de Embu (SP, Brasil) para a conservação da flora regional. Biota Neotropica 7 . Available at http://www.biotaneotropica.org.br/ $\mathrm{v} 7 \mathrm{n} 3 / \mathrm{pt} / \mathrm{abstract}$ article+bn02507032007 (access in 01.11.2008).

Fundação S.O.S. Mata Atlântica \& INPE. 2008. Atlas dos remanescentes florestais da Mata Atlântica. Período 2000 a 2005. Fundação S.O.S. Mata Atlântica e Instituto Nacional de Pesquisas Espaciais, São Paulo.

Gomes, E.P.C., Fish, S.T. \& Mantovani, W. 2005. Estrutura e composição do componente arbóreo na Reserva Ecológica do Trabiju, Pindamonhangaba, SP, Brasil. Acta Botanica Brasilica 19: 451-464.

Guilherme, F.A.G., Morellato, L.P.C. \& Assis, M.A. 2004. Horizontal and vertical tree community structure in a lowland Atlantic Rain Forest, Southeastern Brazil. Revista Brasileira de Botânica 27: 725-737.

Hammer, Ø., Harper, D.A.T. \& Ryan, P.D. 2001. PAST: Paleontological Statistics Software Package for Education and Data Analysis. Palaeontologia Electronica 4(1) (electronic version).
Hill, M.O. \& Gauch, H.G. 1980. Detrended correspondence analysis, an improved ordination technique. Vegetatio 42: 47-58.

Instituto Florestal. 2006. Plano de manejo do Parque Estadual da Serra do Mar. Available at http://www. iflorestal.sp.gov.br/Plano de manejo/PE SERRA MAR/index.asp (access in 01.11.2008).

Ivanauskas, N.M., Monteiro, R. \& Rodrigues, R.R. 2001. Levantamento florístico de trecho de floresta Atlântica em Pariquera-Açu, SP, Brasil. Naturalia 26: 97-129.

Küchler, A.W. 1988. Aspects of maps. In: A.W. Küchler \& I.S. Zonneveld (eds.). Vegetation mapping, Kluwer Academic Publishers, Dordrecht, pp. 97-104.

Leitão-Filho, H.F. 1994. Diversity of arboreal species in Atlantic rain forest. Anais da Academia Brasileira de Ciências 66: 91-96.

Lorenzi, H. 2002a. Árvores brasileiras: manual de identificação e cultivo de plantas arbóreas nativas do Brasil. v.1. 4 ed. Instituto Plantarum, Nova Odessa.

Lorenzi, H. 2002b. Árvores brasileiras: manual de identificação e cultivo de plantas arbóreas nativas do Brasil. v.2. 2 ed. Instituto Plantarum, Nova Odessa.

Lueder, D.R. 1959. Aerial photographic interpretation, principles and applications. MacGraw-Hill, New York.

Mantovani, W. 1993. Estrutura e dinâmica da floresta atlântica na Juréia, Iguape, SP. Tese de Livre-docência, Universidade de São Paulo, São Paulo.

McCune, B. \& Mefford, M.J. 1999. PC-ORD Multivariate analysis of ecological data, v.4.0. MjM Software Design, Gleneden Beach.

Medeiros, M.C.M.P. \& Aidar, M.P.M. 2011. Structural variation and content of aboveground living biomass in an area of Atlantic Forest in the State of São Paulo, Brazil. Hoehnea 38: 413-428.

Melo, M.M.R.F. \& Mantovani, W. 1994. Composição florística e estrutura de trecho de Mata Atlântica de encosta, na Ilha do Cardoso (Cananéia, SP, Brasil). Boletim do Instituto de Botânica 9: 107-158.

Morellato, L.P.C. \& Haddad, C.F.B. 2000. Introduction: The Brazilian Atlantic Forest. Biotropica 32: 786-792.

Mori, S.A., Boom, B.M. \& Prance, G.T. 1981. Distribution patterns and conservation of eastern Brazilian coastal forest tree species. Brittonia 33: 233-245.

Myers, N., Mittermeir, R.A., Mittermeir, C.G., Fonseca, G.A.B. \& Kent, J. 2000. Biodiversity hotspots for conservation priorities. Nature 403: 853-858.

Ogata, H. \& Gomes, E.P.C. 2006. Estrutura e composição da vegetação no Parque CEMUCAM, Cotia, SP. Hoehnea 33: 371-384.

Oliveira-Filho, A.T., Curi, N., Vilela, E.A. \& Carvalho, D.A. 2001. Variation on tree community composition and structure with changes in soil properties within a fragment of semideciduous forest in South-Eastern Brazil. Edinburgh Journal of Botany 58: 139-158. 
Oliveira-Filho, A.T. \& Fontes, M.A.L. 2000. Patterns of floristic differentiation among Atlantic Forests in Southeastern Brazil, and the influence of climate. Biotropica 32: 793-810.

Peccinini, A.A. \& Pivello, V.R. 2002. A vegetação do Parque Estadual das Fontes do Ipiranga (PEFI). In: D.C. Bicudo, M.C. Forti \& C.E.M. Bicudo (orgs.). Parque Estadual das Fontes do Ipiranga: unidade de conservação que resiste à urbanização de São Paulo, Secretaria do Meio Ambiente do Estado de São Paulo, São Paulo, pp. 75-92.

Radambrasil. 1983. Projeto Radambrasil: levantamento de recursos naturais. Instituto Brasileiro de Geografia e Estatística, Rio de Janeiro.

Resende, M., Lani, J.L. \& Rezende, S.B. 2002. Pedossistemas da Mata Atlântica: considerações pertinentes sobre a sustentabilidade. Revista Árvore 26: 261-269.

Sánchez-Azofeifa, G.A., Quesada-Mateo, C., GonzalezQuesada, P., Dayanandan, S. \& Bawa, K.S. 1999. Protected areas and conservation of biodiversity in the tropics. Conservation Biology 13: 407-411.

Sanchez, M., Pedroni, F., Leitão-Filho, H.F. \& César, O. 1999. Composição florística de um trecho de floresta ripária na Mata Atlântica em Picinguaba, Ubatuba, SP. Revista Brasileira de Botânica 22: 31-42.

São Paulo. 1972. Atlas pluviométrico do Estado de São Paulo. Secretaria de Serviços e Obras Públicas, São Paulo.

Setzer, J. 1966. Atlas climático e ecológico do Estado de São Paulo. Comissão Interestadual da Bacia Paraná-Uruguai, São Paulo.
Silva, A.F. \& Leitão-Filho, H.F. 1982. Composição florística e estrutura de um trecho da mata atlântica de encosta no município de Ubatuba (São Paulo, Brasil). Revista Brasileira de Botânica 5: 43-52.

Spurr, S.H. 1960. Photogrammetry and photo-interpretation. 2 ed. Ronald Press Co, New York.

Tabarelli, M. 1997. A regeneração da floresta atlântica montana. Tese de Doutorado, Universidade de São Paulo, São Paulo.

Tabarelli, M. \& Mantovani, W. 1999. A regeneração de uma floresta tropical montana após corte e queima (São Paulo-Brasil). Revista Brasileira de Biologia 59: 239-250.

Tabarelli, M. \& Mantovani, W. 2000. Gap-phase regeneration in a tropical montane forest: the effects of gap structure and bamboo species. Plant Ecology 148: 149-155.

Veloso, H.P., Rangel-Filho, A.L.R. \& Lima, J.C. 1991. Classificação da vegetação brasileira adaptada a um sistema universal. Instituto Brasileiro de Geografia e Estatística, Rio de Janeiro.

Villani, J.P. 1998. Plano de manejo das unidades de conservação: Parque Estadual da Serra do Mar - Núcleo Santa Virgínia. Plano de Gestão Ambiental - Fase 1. Secretaria do Meio Ambiente do Estado de São Paulo, São Paulo.

Zipparo, V.B., Guilherme, F.A.G., Almeida-Scabbia, R.J. \& Morellato, L.P.C. 2005. Levantamento florístico de floresta atlântica no sul do Estado de São Paulo, Parque Estadual Intervales, Base Saibadela. Biota Neotropica 5. Available at http://www.biotaneotropica.org.br/ v5n1/abstract ?inventory+BN02605012005 (access in 01.11.2008). 
